\title{
Glucose Metabolism in the Newborn Rat: The Role of Insulin
}

\author{
K. Snell and D.G. Walker \\ Department of Biochemistry, University of Birmingham, Birmingham, U. K.
}

\begin{abstract}
Summary. The effect of the administration of antiinsulin serum to newborn rats, surgically delivered under ether anaesthesia at term, was examined with respect to liver glycogen concentration and plasma concentrations of glucose, lactate and free fatty acids. Newborn rats thus treated showed decreased liver glycogen concentrations and elevated plasma concentrations of glucose, lactate and free fatty acids compared to untreated control animals one hour later. These effects were dose-dependent with respect to the amount of anti-insulin serum administered. The simultaneous administration of glucagon with anti-insulin serum at birth was no more effective in mobilising glycogen stores than anti-insulin serum alone, although plasma glucose concentrations in these animals were higher and plasma lactate concentrations were lower. Either anti-insulin serum or glucagon abolished the postnatal hypoglycaemia observed in untreated neonatal rats. The rate of fall in plasma lactate concentrations after birth was stimulated in glucagon-treated rats but was retarded in rats treated with anti-insulin serum. Hormonal control over the initiation of glycogenolysis and gluconeogenesis in the newborn rat appears to be different, a fall in plasma insulin being the prime factor involved in triggering glycogen mobilization and a rise in plasma glucagon the prime event that initiates gluconeogenesis.
\end{abstract}

Key words: Insulin, anti-insulin serum, glucagon, glycogen, glucose, lactate, free fatty acids, fetus, newborn, neonatal hypoglycaemia.

Before birth the fetal rat receives its nutrient supply from the maternal circulation via the placenta. The cessation of the continuous transplacental nutrient supply at birth imposes a new environmental situation on the newborn animal to which it must rapidly adapt for extrauterine survival. The most immediate response after birth is the mobilisation and oxidation of endogenous reserves until dietary nutrients are provided by the suckling mother. This period of 2-3 hours before feeding begins is associated, in naturally and surgically delivered rats, with a transient period of pronounced hypoglycaemia [1-6], which is the result of an increased rate of glucose utilization relative to the rate of glucose formation [4]. Recovery from the hypoglycaemic phase, which commences before feeding begins, seems to be primarily due to a marked decrease in the rate of glucose utilization and coincides with the breakdown of the large hepatic store of glycogen which has been built up during late fetal life. There appears to be a delay of 1-2 hours after birth in the mobilization of the glycogen store [1, 3-6]. The capacity for hepatic gluconeogenesis is also acquired postnatally. This metabolic process appears about $30 \mathrm{~min}$ after delivery $[4,7]$ and results in decreases in the concentrations of the circulating glucogenic substrates, lactate and amino acids $[4,6]$. The factors controlling the initiation of gluconeogenesis and glycogenolysis in the rat immediately after birth are not clear. The present study was undertaken to determine more precisely the role of insulin in the adaptive changes in carbohydrate metabolism which take place in the newborn rat.

\section{Materials and Methods}

The rats were an albino Wistar strain. Fetal ages were determined as previously described [8] and term fetuses (on day 22 of gestation) were delivered by caesarian section after lightly anaesthetising 
Table 1. Effect of anti-insulin serum on hepatic glycogen and plasma glucose, lactate and free fatty acid concentrations in newborn rats. Experimental conditions are as in Figure 1 . All injections were given immediately after delivery. Results are given as the means \pm SEM with the number of determinations in parentheses. Each determination was on the liver from a single animal or the plasma pooled from two animals. Significance of results compared to untreated controls at $1 \mathrm{~h}$ : $\mathrm{p}<0.001$

\begin{tabular}{|c|c|c|c|c|}
\hline & $\begin{array}{l}\text { Liver glycogen } \\
\text { concentration } \\
\text { ( } \mu \mathrm{mol} \text { glucose/g liver) }\end{array}$ & $\begin{array}{l}\text { Plasma glucose } \\
\text { concentration } \\
(\mathrm{mmol} / \mathrm{l})\end{array}$ & $\begin{array}{l}\text { Plasma lactate } \\
\text { concentration } \\
(\mathrm{mmol} / \mathrm{l})\end{array}$ & $\begin{array}{l}\text { Plasma free } \\
\text { fatty acid } \\
\text { concentration } \\
(\mathrm{mEq} / 1\end{array}$ \\
\hline \multicolumn{5}{|l|}{ Untreated control } \\
\hline At birth & $470 \pm 14(9)$ & $9.41 \pm 0.56(8)$ & $12.28 \pm 0.44(6)$ & $0.37 \pm 0.07(4)$ \\
\hline $1 \mathrm{~h}$ post partum & $470 \pm 11(9)$ & $2.78 \pm 0.23(6)$ & $5.08 \pm 0.18(6)$ & $0.42 \pm 0.09(4)$ \\
\hline \multicolumn{5}{|l|}{ Normal guinea-pig serum } \\
\hline $1 \mathrm{~h}$ post partum & $446 \pm 19(6)$ & $3.29 \pm 0.31(6)$ & $5.50 \pm 0.28(6)$ & $0.45 \pm 0.06(4)$ \\
\hline \multicolumn{5}{|l|}{ Guinea-pig anti-insulin serum } \\
\hline $1 \mathrm{~h}$ post partum $(30 \mu \mathrm{l}$ at birth $)$ & $406 \pm 10(6)^{*}$ & $9.20 \pm 0.33(6)^{*}$ & $7.52 \pm 0.24(6)^{*}$ & $0.97 \pm 0.10(4)^{*}$ \\
\hline $1 \mathrm{~h}$ post partum $(60 \mu \mathrm{l}$ at birth) & $356 \pm 14(9) *$ & $10.06 \pm 0.49(8)^{*}$ & $9.24 \pm 0.62(6)^{*}$ & $1.53 \pm 0.12(6)^{*}$ \\
\hline \multicolumn{5}{|l|}{$\begin{array}{l}\text { Guinea-pig anti-insulin serum } \\
(60 \mu \mathrm{l})+\text { glucagon }(50 \mu \mathrm{g})\end{array}$} \\
\hline $1 \mathrm{~h}$ post partum & $330 \pm 12(6)^{*}$ & $16.60 \pm 0.52(6)^{*}$ & $4.36 \pm 0.20(6)^{*}$ & \\
\hline
\end{tabular}

the mother with an ether-air mixture. The fetuses were delivered with the placentas intact within one minute of maternal anaesthesia, and then promptly detached within 3 minutes of delivery after first tying the umbilical cords. The animals were then maintained in a humid atmosphere in an incubator at an ambient temperature of $35 \pm 1^{\circ} \mathrm{C}$ without feeding.

In the experiments in Table 1 a total of 9 litters were used; each litter provided animals that were untreated, treated with normal guinea-pig serum, anti-insulin serum at two dose levels ( 30 or 60 $\mu \mathrm{l} / \mathrm{rat}$ ), or anti-insulin serum + glucagon. The values in the Table are the means of measurements in animals from all the litters; statistical analysis (t-test) was carried out on observations paired within a single litter. Similar protocols were used in the other experiments reported and the number of litters used is indicated in the appropriate legend to the Figures.

Newborn rats were injected intraperitoneally 10-15 min after delivery by means of an Agla micrometer syringe (Burroughs Wellcome and Co., Beckenham, Kent. U. K.). Glucagon (Eli Lilly and Co. Ltd. Basingstoke, Hants., U.K.) was administered at a dose of $50 \mu \mathrm{g}$ per rat, guinea-pig serum (from normal uninjected guinea-pigs) at a dose of $60 \mu \mathrm{l}$ per rat and guinea-pig anti-insulin serum at various doses as indicated in the text. The anti-insulin serum (raised against bovine insulin) was a gift from Mr. D. Baxter, Wellcome Research Laboratories, Dartford, Kent, and had an insulin neutralising capacity of $1 \mathrm{mU} / \mu \mathrm{l}$ against ox insulin. After injection rats were killed at intervals by decapitation without anaesthesia and blood samples were col- lected on squares of Parafilm containing heparin (100 international units), on ice. After centrifugation of the blood at $4^{\circ} \mathrm{C}$, the plasma was removed and stored on ice. Immediately after exsanguination, livers were rapidly removed and then weighed and digested in $30 \%(\mathrm{w} / \mathrm{v}) \mathrm{KOH}$ in a boiling water bath. There was a delay of $30 \mathrm{sec}$ from the time of decapitation to the time of mixing of the liver with $\mathrm{KOH}$. Glycogen was isolated as described by Cowgill \& Pardee [9] and glycogen concentration was determined after enzymic hydrolysis with Agidex (British Drug Houses Ltd., Poole, Dorset, U. K.), a commercial glucoamylase preparation, as described by Vernon \& Walker [10]. Glycogen-derived glucose was estimated as described below. Samples of plasma $(0.1 \mathrm{ml})$ were deproteinised with $0.9 \mathrm{ml}$ of $0.27 \mathrm{M}-\mathrm{HC}_{4}$. Glucose concentration was estimated by a glucose oxidase method [11] and $L$-lactate concentration was estimated, after neutralization of the protein-free supernatant, by the enzymic method of Hohorst [12]. Free fatty acid concentrations were colorimetrically estimated in whole plasma as described by Chernick \& Novak [13] using palmitic acid as the reference standard and including a set of standards with every group of determinations.

\section{Results}

Untreated newborn rats showed no change in liver glycogen concentration in the first hour after delivery and an insignificant decrease after the administration of normal guinea-pig serum. However, injections of anti-insulin serum immediately after delivery produced a significant fall in liver glycogen 


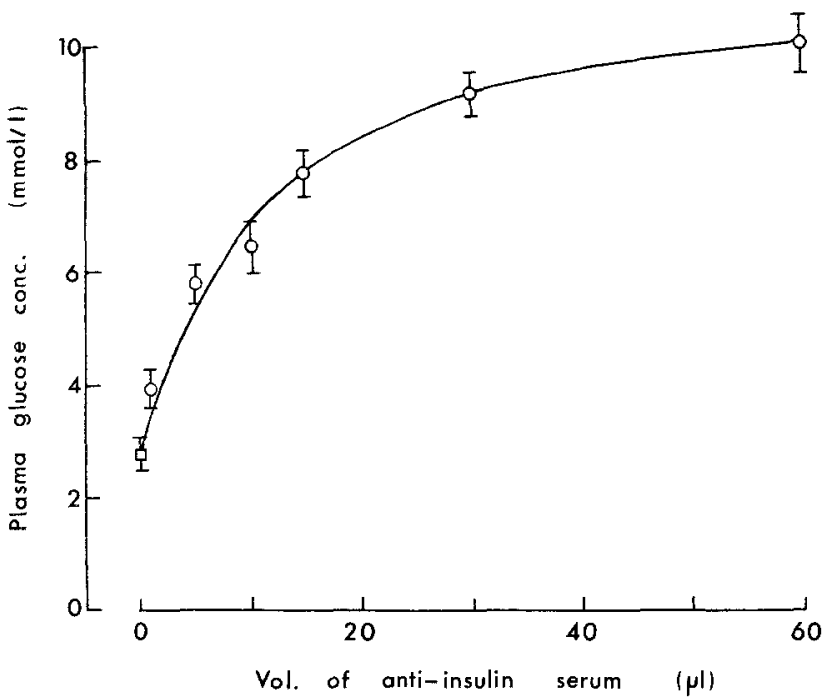

Fig. 1. Effect of varying amounts of anti-insulin serum on plasma glucose concentrations in newborn rats. Term fetuses were delivered by caesarian section and, after intraperitoneal injection with normal guinea-pig serum ( $\square$ ) or varying amounts of guinea-pig anti-insulin serum $(O)$, the newborn rats were maintained without feeding in an incubator at $35^{\circ} \mathrm{C}$ and killed at $1 \mathrm{~h}$ post partum. Each point represents the mean (bars show \pm SEM) of 5-8 determinations; each determination was made on the plasma pooled from two animals. A total of eight litters were employed in these experiments

concentration at $1 \mathrm{~h}$ post partum and a significant rise in plasma glucose concentration compared with control animals (Table 1). Plasma lactate and free fatty acid concentrations were raised in animals treated with anti-insulin serum compared with control groups.

The high plasma glucose concentrations in untreated control rats at birth were some $15 \%$ higher than in newborn surgically delivered from unanaesthetised dams killed by cervical dislocation (K. Snell, unpublished observation), and this small difference may be attributable to a possible brief transplacental exposure of fetuses to the ether anaesthetic.

The high plasma lactate concentrations at birth (Table 1) were not significantly different from values in newborn delivered from unanaesthetised dams (K. Snell, unpublished observations) or in naturally delivered newborn [14] and reflect the high rate of glucose utilization at this time [4]. The effects of anti-insulin serum on these variables were dose-dependent; $60 \mu \mathrm{l}$ of anti-insulin serum produced a greater response than $30 \mu \mathrm{l}$ (Table 1). Figure 1 shows a more complete anti-insulin doseresponse curve with respect to plasma glucose concentration; the response appeared to be maximal at a dose of about $60 \mu \mathrm{l}$ anti-insulin serum per rat.

When glucagon $(50 \mu \mathrm{g})$ was injected together with anti-insulin serum the decrease in liver glyco- gen concentration was not statistically greater than in animals treated with anti-insulin serum alone (Table 1). The plasma glucose concentration was markedly greater $(p<0.001)$ and the plasma lactate concentration was markedly less $(p<0.001)$ in animals that received both agents compared with those receiving anti-insulin serum alone. Significant differences in plasma glucose and lactate concentrations were also observed between animals receiving glucagon and anti-insulin serum together and control serum-treated animals ( $p<0.01$ or better) or untreated control animals $(\mathrm{p}<0.001)$.

Figure 2 shows the time-course of changes in plasma glucose and lactate concentrations after injection of rats at delivery with saline, anti-insulin serum or glucagon. In both glucagon-treated and anti-insulin serum-treated animals plasma glucose concentrations were maintained at a constant level, albeit at slightly different values for the different agents, from $15 \mathrm{~min}$ to at least $60 \mathrm{~min}$ after injection. In control animals the plasma glucose concentration fell rapidly after saline injection, as was observed previously for untreated animals after delivery [4]. The fall in plasma lactate concentration that occurs after birth in saline-treated rats was accelerated by glucagon injection (e.g. p $<0.001$ for 45 min time-points) and retarded by injection of antiinsulin serum (e.g. $p<0.001$ for $45 \mathrm{~min}$ timepoints).

\section{Discussion}

Some comments on the neonatal rat model employed in the present work are merited. In order to carry out studies on the detailed time-course of blood metabolite levels after parturition, rats were delivered by caesarian section from ether-anaesthetised dams on the last day of gestation, within a few minutes of their littermates and then maintained without feeding in an incubator at $35^{\circ} \mathrm{C}$. However, identical metabolite changes, including the transient phase of postnatal hypoglycaemia, are observed in rats surgically delivered after cervical dislocation of the mother in the absence of anaesthesia (K. Snell, unpublished observations; [6, 15]), in rats surgically delivered under ether anaesthetic and immediately placed with a fostermother [4], or in rats spontaneously and naturally delivered $[2,3]$.

In a recent study [16] of blood glucose concentrations following natural delivery no postnatal hypoglycaemic phase was observed, but this may have been due to disturbances of maternal nursing and, because of thermogenic immaturity, to hypothermia, which is known to prevent postnatal hypoglycaemia [17], or to the use of ether anaesthesia for 

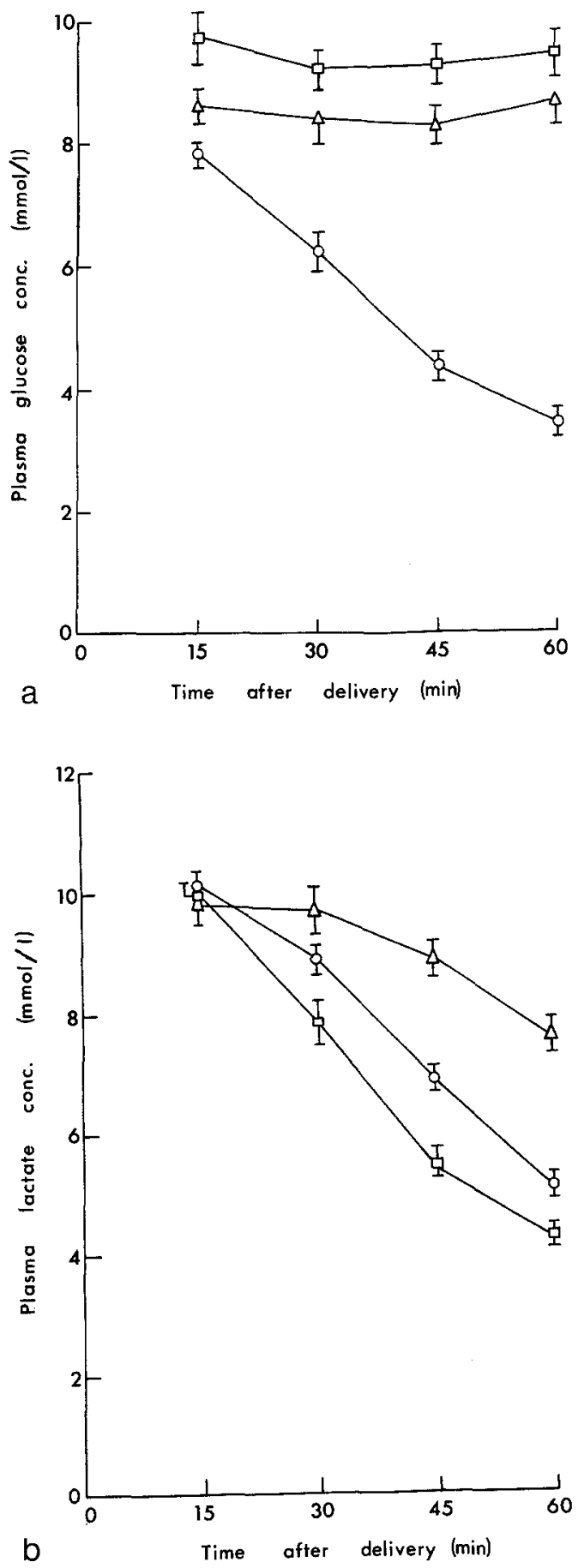

Fig. 2. Effect of anti-insulin serum or glucagon on the time-course of a plasma glucose and $\mathbf{b}$ plasma lactate concentrations in newborn rats. Experimental conditions are as in Figure 1. Newborn rats were injected with saline $(O)$, glucagon $(\square)(50$ $\mu \mathrm{g} / \mathrm{rat})$, or anti-insulin serum $(\Delta)(30 \mu \mathrm{l} / \mathrm{rat})$ and killed at timeintervals after injection. Each point represents the mean (bars show \pm SEM) of 4-6 determinations; each determination was made on the plasma pooled from two animals. A total of twelve litters were employed in these experiments killing the neonatal rats at the various times after birth. With these considerations in mind we submit that the model employed in the present work largely reflects the normal physiological changes in metabolites that occur in the rat after natural birth.

The interpretation of the findings in our study depends on a knowledge of the precise temporal changes in the circulating concentrations of the pancreatic hormones, glucagon and insulin, after parturition. Plasma glucagon levels rise after birth to reach a maximum value after $30 \mathrm{~min}$, whereas plasma insulin concentrations are high at birth and decrease to reach a low steady value between one and two hours [6]. The lag in the onset of glycogen breakdown after birth is associated with the high plasma insulin concentrations at this time and these decrease to much lower values at the same time as a measurable decrease in hepatic glycogen concentration occurs [4-6]. The initial lack of glycogen breakdown occurs despite the marked rise in plasma glucagon concentration by $30 \mathrm{~min}$ post partum [6] and, furthermore, exogenous glucagon or cyclic AMP administered at birth is also without effect on immediate glycogen breakdown [18]. It is known in the adult rat that insulin can antagonise the glycogenolytic action of glucagon in the liver [19-21]. The effect of anti-insulin serum at birth to promote a prompt decrease in liver glycogen concentration (Table 1) suggests that such an antagonistic action of insulin may restrict glucagon action in the newborn rat, although an effect of insulin that is independent of any interaction with glucagon is also possible (see below).

A coincident mobilization of liver glycogen and a decrease in the plasma insulin concentration has also been observed in utero in postmature foetuses subjected to experimentally-induced prolongation of gestation [15]. These changes occurred despite blood glucose levels in the postmature animals being similar to those in normal term fetuses and suggest that a fall in blood glucose concentration (as found in term animals after delivery) is not an obligatory factor causing the observed changes. Similarly, in the present work, the stimulation of glycogen breakdown by anti-insulin serum at birth occurred despite the maintenance of plasma glucose concentrations at the levels found at delivery (Table 1). The known effects of glucose on the glycogen phosphorylase and glycogen synthetase activation - inactivation cycles $[22,23]$ may therefore be of minor significance in controlling postnatal glycogenolysis.

It is possible that glucagon may not be involved in the initiation of glycogen mobilization immediately after birth, although it may play a long-term role in maintaining the continuous breakdown of hepatic 
glycogen. There is no immediate effect of glucagon or its intracellular messenger, cyclic AMP, on the enzymes of glycogen metabolism in fetal rats [24, $25]$, or on liver glycogen concentration in the first hour after delivery [18]. However, in the long-term, glucagon injection to fetal rats has been reported to reduce glycogen concentrations measured 3-6 h after hormone injection [26, 27, 28, 29], although the interpretation of these experiments is difficult because of the glycogenolytic effects of prolonged exposure of the fetuses to ether or pentobarbital anaesthetic agents [25]. Glucagon given in repeated doses to naturally delivered newborn rats stimulated glycogen breakdown at 4 hours after birth, but earlier times were not investigated [30].

On the basis of the present observations with anti-insulin serum and previous work on the lack of effect of glucagon or cyclic AMP [18], it is proposed that the initiation of glycogen breakdown after birth is triggered by the fall in circulating insulin concentrations. If this is so one would expect the administration of insulin to newborn rats to inhibit postnatal glycogenolysis. Several studies using a single injection of insulin at birth have failed to demonstrate an inhibitory action $[1,28]$, but in a study where multiple injections were employed glycogenolysis was inhibited at 4 hours after birth [31]. The failure of a single insulin injection to inhibit glycogenolysis may have been due to a rapid inactivation and breakdown of the exogenous insulin (as occurs with endogenous insulin [6]) and support for this comes from experiments in which administration of glucose to rats at birth, which causes a sustained release of insulin [17], is effective in preventing glycogenolysis $[1,28,31]$. The initiation of glycogen breakdown by anti-insulin serum or by the fall in plasma insulin postnatally is unlikely to be mediated by an increase in intrahepatic cyclic AMP, since exogenous administration of this agent is ineffective in promoting glycogenolysis at birth [18]. Recent observations have demonstrated an action of insulin on glycogen metabolism that is independent of cyclic AMP [32, 33 ], and this control system may be operative in the newborn rat in the period immediately following birth.

The role of insulin, if any, in controlling the initiation of gluconeogenesis postnatally is difficult to define. A fall in lactate concentration, albeit less than in control animals, occurs simultaneously with the anti-insulin serum-mediated hyperglycaemia in the newborn rat (Table, 1 Fig. 2) suggesting that lactate might be serving as a glucogenic substrate. The fall in lactate could also be due to a reduction in the insulin-mediated utilization of glucose by peripheral tissues, which is high at this time [4]. In any case anti-insulin serum is without effect on the postnatal increase in plasma glucagon concentrations (at least at 1 hour post partum [34]), so that it is not possible to distinguish the effects of the natural rise in glucagon from those due to the experimentally-induced fall in insulin in this situation. Glucagon administered at delivery increases the rate of body glucose formation and the incorporation of ${ }^{14} \mathrm{C}$ lactate into plasma glucose [18], elevates the plasma glucose concentration, and lowers the plasma lactate concentration compared to untreated newborn rats (Figure 2). Glucagon administered to newborn rats prematurely induces the synthesis of phosphoenolpyruvate carboxykinase, the rate-limiting enzyme in the gluconeogenic pathway at birth $[2,35]$. These responses occur at the time when the plasma insulin concentration is still high suggesting that the postnatal increase in plasma glucagon may be the major factor involved in initiating gluconeogenesis.

Some of the other temporal changes in metabolites observed immediately after birth in the rat [4] may also be interpreted on the basis of the changing concentration of insulin. Thus, plasma free fatty acid concentrations do not show any significant increase until 1-2 $\mathrm{h}$ after delivery [4] but are considerably elevated within one hour of injection of anti-insulin serum at birth (Table 1). The rat at birth has very little fat stores and these are entirely in the form of brown adipose tissue [36]. The postnatal increase in plasma free fatty acid concentrations occurs regardless of the onset of suckling [4] and, presumably, reflects lipolysis in brown adipose tissue. In the newborn rabbit insulin inhibits the release of free fatty acids by brown adipose tissue [37] and, in vivo, insulin levels in the blood decrease before glycerol release from brown adipose tissue occurs [38]. It seems likely that the effect of anti-insulin serum in the present experiments is to alleviate this inhibitory effect of insulin on free fatty acid release by adipose tissue.

The present observations in the rat must obviously be viewed with caution when extrapolating to other species. However, transient hypoglycaemia, hyperglucagonaemia and hypoinsulinaemia have been reported in normal human newborn [39, 40, 41]. The use of the neonatal rat as a model system may provide insights into the mechanisms involved in glucoregulatory disturbances observed in certain human pathophysiological states. The present work has drawn attention to the possibility that different regulatory mechanisms are involved in the postnatal initiation of glycogenolysis and gluconeogenesis, both of which are important glucose homoeostatic mechanisms by which the newborn animal accomplishes the transition from the intrauterine to the extrauterine environment. 


\section{References}

1. Dawkins, M.J.R.: Glycogen synthesis and breakdown in foetal and newborn rat liver. Ann. N. Y. Acad. 111, 203-211 (1963)

2. Yeung, D., Oliver, I. T.: Factors affecting the premature induction of phosphopyruvate carboxylase in neonatal rat liver. Biochem. J. 108, 325-331 (1968)

3. Cake, M.H., Yeung, D., Oliver, I.T.: The control of postnatal hypoglycaemia. Biol. Neonate 18, 183-192 (1971)

4. Snell, K., Walker, D. G.: Glucose metabolism in the newborn rat: temporal studies in vivo. Biochem. J. 132, 739-752 (1973)

5. Ballard, F. J.: Gluconeogenesis and the regulation of blood glucose in the neonate. In: R. R. Rodriguez, J. VallanceOwen (Eds.): Diabetes, pp. 592-600. Amsterdam: Excerpta Medica Foundation (1971)

6. Girard, J.R., Cuendet, G.S., Marliss, E. B., Kervran, A., Rieutort, M., Assan, R.: Fuels, hormones, and liver metabolism at term and during the early postnatal period in the rat. J. Clin. Invest. 52, 3190-3200 (1973)

7. Ballard, F. J.: The development of gluconeogenesis in rat liver. Controlling factors in the newborn. Biochem. J. 124, 265-274 (1971)

8. Snell, K., Walker, D.G.: The adaptive behaviour of isoenzyme forms of rat liver alanine aminotransferases during development. Biochem. J. 128, 403-413 (1972)

9. Cowgill, R.W., Pardee, A.B.: Isolation and hydrolysis of liver glycogen. In: Experiments in biochemical research techniques, pp. 158-159. New York: Wiley \& Sons 1957

10. Vernon, R.G., Walker, D.G.: Glycerol metabolism in the neonatal rat. Biochem. J. 118, 531-536 (1970)

11. Krebs, H. A., Bennett, D.A.H., de Gasquet, P., Gascoyne, T., Yoshida, T.: Renal gluconeogenesis. The effect of diet on the gluconeogenic capacity of rat kidney. Biochem. J. 86, 22-27 (1963)

12. Hohorst, H.J.: L-lactate. In: H. U. Bergmeyer (Ed.): Methods of Enzymatic Analysis, pp. 266-270. New York: Academic Press 1963

13. Chernick, S., Novak, M.: Effect of insulin on FFA mobilization and ketosis in fasting pregnant rats. Diabetes 19 , 563-570 (1970)

14. Vernon, R.G., Walker, D. G.: Glucose metabolism in the developing rat, studies in vivo. Biochem. J. 127, 521-529 (1972)

15. Portha, B., Rosselin, G., Picon, L.: Postmaturity in the rat: impairment of insulin, glucagon, and glycogen stores. Diabetologia 12, 429-436 (1976)

16. Gain, K., Watts, C.: Blood glucose, plasma insulin and hepatic glycogen in the newborn rat. Biol. Neonate 30, 35-39 (1976)

17. Kervran, A., Gilbert, M., Girard, J. R., Assan, R., Jost, A.: Effect of environmental temperature on glucose-induced insulin response in the newborn rat. Diabetes 25, 1026-1030 (1976)

18. Snell, K., Walker, D. G.: Glucose metabolism in the newborn rat: hormonal effects in vivo. Biochem. J. 134, 899-906 (1973)

19. Mackrell, D. J., Sokal, J. E.: Antagonism between the effects of insulin and glucagon on the isolated liver. Diabetes $\mathbf{1 8}$, 724-732 (1969)

20. Glinsman, W.H., Mortimore, G. E.: Influence of glucagon and 3', 5'-AMP on insulin responsiveness of the perfused rat liver. Am. J. Physiol. 215, 553-559 (1968)

21. Exton, J.H., Lewis, S.B., Ho, R. J., Robison, G. A., Park, C. R.: The role of cyclic AMP in the interaction of glucagon and insulin in the control of liver metabolism. Ann. N. Y. Acad. Sci. 185, 85-100 (1971)

22. Stalmans, W., de Wulf, H., Hue, L., Hers, H.-G.: The se- quential inactivation of glycogen phosphorylase and activation of glycogen synthetase in liver after the administration of glucose to mice and rats. Eur. J. Biochem. 41, 127-134 (1974)

23. Pines, M., Bashan, N., Moses, S. W.: Glucose effect on glycogen synthetase and phosphorylase in fetal rat liver. FEBS Lett. 62, 301-303 (1976)

24. Pines, M., Bashan, N., Moses, S. W.: Effect of hydrocortisone and glucagon on glycogen metabolism in the fetal rat liver. Biochim. Biophys. Acta 411, 369-376 (1975)

25. Devos, P., Hers, H.-G.: Glycogen metabolism in the liver of the foetal rat. Biochem. J. 140, 331-340 (1974)

26. Hunter, D. J. S.: Changes in blood glucose and liver carbohydrate after intrauterine injection of glucagon into foetal rats. J. Endocrinol. 45, 367-374 (1969)

27. Greengard, D., Dewey, H.K.: The premature deposition or lysis of glycogen in livers of fetal rats injected with hydrocortisone or glucagon. Dev. Biol. 21, 452-461 (1970)

28. Girard, J. R., Caquet, D., Bal, D., Guillet, I.: Control of rat liver enzymes by insulin and glucagon during the perinatal period. Enzyme 15, 272-285 (1973)

29. Chiu, H.F., Phillips, M.J.: Glucagon induces premature structural differentiation of fetal hepatocytes. Lab. Invest. 30, 305-310 (1974)

30. Kotoulas, O.B., Phillips, M.J.: Fine structural aspects of the mobilisation of hepatic glycogen, I. Acceleration of glycogen breakdown. Am. J. Pathol. 63, 1-21 (1971)

31. Kotoulas, O.B., Ho, J., Adachi, F., Weigensberg, B. I., Phillips, M.J.: Fine structural aspects of the mobilisation of hepatic glycogen, II. Inhibition of glycogen breakdown. Am. J. Pathol. 63, 23-26 (1971)

32. Van de Werve, G., Hue, L., Hers, H.-G.: Hormonal and ionic control of the glycogenolytic cascade in rat liver. Biochem. $\mathbf{J}$. 162, 135-142 (1977)

33. Van de Werve, G., Stalmans, W., Hers, H.-G.: The effect of insulin on the glycogenolytic cascade and on the activity of glycogen synthetase in the liver of anaesthetised rabbits. Biochem. J. 162, 143-146 (1977)

34. Girard, J. R., Kervran, A., Assan, R.: Functional maturation of the A-cell in the rat. In: R. A. Camerine-Da Valos, H.S. Cole (Eds.): Early Diabetes in Early Life, pp. 57-71. New York: Academic Press 1975

35. Philippidis, H., Ballard, F. J.: The development of gluconeogenesis in rat liver. Effects of glucagon and ether. Biochem. J. 120, 385-392 (1970)

36. Hahn, P., Novak, M.: Development of brown and white adipose tissue. J. Lipid Res. 16, 79-91 (1975)

37. Hardman, M.J., Hull, D.: The action of insulin on brown adipose tissue in vivo. J. Physiol. 221, 85-92 (1972)

38. Hardman, M.J., Hull, D., Milner, R.D.: Brown adipose tissue metabolism in vivo and serum insulin concentrations in rabbits soon after birth. J. Physiol. 213, 175-183 (1971)

39. Mulligan, P. B., Schwartz, R.: Hepatic metabolism in neonatal hypoglycaemia. Am. J. Dis. Child, 102, 490-496 (1961)

40. Pribylora, H., Rylander, E.: Free fatty acids, glycerol, glucose and $\beta$-hydroxybutyrate of plasma of infants protected from cooling and exposed to cold at various times after birth. Biol. Neonate 20, 425-435 (1972)

41. Sperling, M. A., DeLamater, P. V., Phelps, D., Fiser, R.H. Oh, W., Fisher, D. A.: Spontaneous and amino acid-stimulated glucagon secretion in the immediate postnatal period. J. Clin. Invest. 53, 1159-1166 (1974)

Received: April 26, 1977, and in revised form: August 9, 1977

Dr. K. Snell

Department of Biochemistry

University of Surrey

Guilford, Surrey GU2 5XH

England 